\title{
New Wine and Old Bottles? Tele-Learning, Telematics and the University of Twente
}

\author{
B. Collis
}

Faculteit Toegepaste Onderwijskunde, (Faculty of Educational Science and Technology)

Universiteit Twente (University of Twente)

e-mail:collis@edte.utwente.nl

\section{Keywords}

Tele-learning, Intellectual development, Internationalisation, Implementation strategy

\section{AN ANNIVERSARY: THOUGHTS OF NEW AND OLD, OF CELEBRATION AND FINE WINE}

Today, November $28^{\text {th }}$, is an anniversary celebration for the University of Twente. Anniversaries are happy affairs; among their many functions, they bring people together who share some common connection but represent different generations of contact with that common connection. The University of Twente, as our common connection, is not old as universities go, but as an institution it is certainly old enough to have old values, and old ways of going about its business. Today, I want to think about old and new. I want to reflect about the idea of "tele-learning" as something new at the University of Twente, and I want to speculate on what it might mean for our old values, our old ways of doing things at this university. And, because I am thinking in terms of an anniversary and of celebration, I want to use a metaphor that relates to celebrating: I want to frame my thoughts around the idea of wine: old and new, mature or still fermenting, I want to expand upon two apparently contradictory parables about wine, and draw messages from these for the University of Twente, telematics, and tele-learning.

\section{BUT FIRST, A DEFINITION IS IMPORTANT}

I am using the term "tele-learning" but I am quite sure that if we had a quiz right now, and each of you had to give a definition of what I mean by this term, there would be many different answers. Some of you would say: "distance education", 
and picture a scenario where a teacher, like me, is talking not only to the group in front of her, but also to a group clustered at a remote location, and watching the teacher via a room-sized videoconferencing system or television or even via a computer screen. The teacher pauses and asks a question--a student at the remote location, indicates by some technological procedure that he wishes to answer and then his voice and face come through a network or the ether into the monitor in the teacher's classroom.

But I imagine many others of you have a different idea: you picture a student, by herself, in her home, surrounded by piles of books and notepads, busily studying, perhaps for a course similar to those offered by the traditional open universities. She has the benefit of studying when and where she wants, but with the consequence that she looses the benefits of interacting with a skilled teacher in a class environment.

These were the two most popular images for tele-learning five years ago, but now there are other contenders. Perhaps you are picturing a situation in a basisschool (elementary school) in your own neighbourhood: the teacher has one of the school computers in the classroom, a computer with a modem that connects to the networks needed to access the Internet. Within this classroom, with the teacher and pupils side by side, the class is able to bring in information about an event, such as the Mars landing as happened in the summer of 1997, taking place somewhere far away in the world (or even out of the world, as in the case of Mars and the Sojourner vehicle). The teacher and pupils not only access up-to-date information as it is occurring, but also are busy exchanging information and ideas with other classes, in different places, about the event, learning on the way about the solar system, distances in space, and geology.

Or perhaps you are picturing a secondary school, where students routinely check resources available in local, regional, national, or international collections, without paying much attention to the fact that one click of their mouse brings them to a computer in a library in Amsterdam, and another click brings them to the computer in a school in Australia where other students such as themselves have made available useful resources via a WWW site. Sometimes their teacher comes in the room as they search for appropriate resources, sometimes she doesn't.

But there are even more scenarios you might have thought of: perhaps you thought of someone like yourselves, no longer a student, but still someone involved in life-long learning. Not through taking courses in an institution, but by accessing information you need when you need it, sometimes by contacting appropriate persons, other times by reading journals or studying conference proceedings or accessing other sources of professional information. More and more, you are probably, like me, doing this via different World Wide Web sites, as well as by other means such as e-mail, telephone, and of course, reading printed text. 
Each of the above scenarios I have described above, and a number of other scenarios $^{1}$, all are part of what I call "tele-learning". To encompass all these possibilities, my definition of tele-learning is:

\section{Using telematics for learning-related purposes}

Notice that this definition does not say anything about geographical distance, one way or the other. This is intentional, because with telematics when we make a connection with persons they may be in the next room or the next continent; when we connect to information with telematics tools, we maybe accumulating it from the hard drives of our own computers, from our own local servers or from computers on the other side of the world. The point is that with telematics, the distance between myself and the persons with whom I am communicating or between myself and the information with which I am working is not particularly relevant.

And there is another point to notice in the above scenarios. In all of them, a variety of ways of interacting, of learning, with a variety of media, and with a variety of communication methods, can be found. This is deliberate: in my definition, good "tele-learning" comes from knowing how and if and when telematics can support some aspect related to learning better than we do it without telematics, and how telematics can be combined with good pedagogy, good thinking, good debate, good books, good face-to-face interaction, and good working and learning habits to improve the quality of a learning experience. By "better", I mean more efficient, or more enriched, or more flexible.

Thus in the rest of these remarks, when I use the term "tele-learning" I mean simply, telematics used in some way related to the learning enterprise.

Now, back to the idea of a wine-related metaphor that I mentioned at the beginning of this talk: Is tele-learning our New Wine...? Or only some new packaging?

\section{TELE-LEARNING AT THE UT, IS ANYTHING REALLY CHANGING?}

Previously I asked you to define "tele-learning" and I guessed that there would be many different definitions, with the "correct answer" being "all of the above". But I also imagine that some of you may have had some other sorts of thoughts. Perhaps when you saw the title "tele-learning" as the theme for this anniversary celebration, your deep-down reaction was that all of this "tele" business is something of a buzzword, a current "hype", similar to buzzwords such as the "information highway" or the "information superhighway" or the "virtual information superhighway" or the "virtual whatever". You may think of the World Wide Web as a fad, a bandwagon, more metaphor than substance, more noise than

\footnotetext{
1 I begin my 1996 book, "Tele-learning in a digital world", with a discussion of 11 such scenarios, and work these out in the subsequent chapters of the book.
} 
real impact. You may be thinking, "Yes, yes, lots of talk but nothing has really changed" in the university enterprise. In fact, this is the first of the wine-related metaphors that I want to use today, the Dutch phrase:

\section{"Oude wijn in nieuwe zakken" (Old wine in new bottles)}

Especially if you have gone through various waves of fascination with other technologies and their possibilities for education, particularly the computer itself, you may feel we should have learned our lessons already, that technologies come and go, but basically don't change the way we teach and learn and how we organise our courses and degree requirements and the way we fund persons to study; or the ways we work with our colleagues and our students. You may well be saying, "Please, no more hype".2

But I don't want to let the idea continue that tele-learning is some kind of new packaging, some kind of superficial add-on, to business as usual in the University. I want to turn the metaphor around, and instead argue the following: At the University of Twente, I see tele-learning not as a new packaging, but as new wine. I present a new metaphor:

\section{New Wine and Old Bottles}

But wait: Is this good or bad? If telematics is the "new wine" in the metaphor, then what are the "old bottles"?

I am going to look at the "old bottles" in two different ways. In the first way, the connotation of this new turned-around metaphor becomes positive, because the definition of "old bottles" that I will use is "old values". I will argue and demonstrate that telematics as a new wine is enhancing and enriching our old values at the University of Twente. In the second way of looking at the old bottlesmetaphor, however, the message is a warning. I discuss this second way in Section 9.

\section{4. "OLD VALUES" AND THE UNIVERSITY}

What are some of the old values that I believe most important to universities, not only Twente? There are many, but the ones I will focus upon today are the following four:

Values related to "academische vorming" (or what Prof. Van Vught, in his rede for the opening of the University year two months' previously, calls becoming an "intellectual expert")

Values relating to good teaching

Values related to the interaction of local and global perspectives; and

2 I followed this line, comparing the response of educators and society to the possibilities of computers in education in the late 1970s with the response today with respect to the Internet and the WWW, in an analysis for UNESCO in 1996. An abridged version of this analysis is published in the journal Educational Technology (Collis, 1996b). 
Values related to the university being a focal point of knowledge and expertise.

For each of these, I will show some examples from today, at the University of Twente, of how these old values are being strengthened and deepened by the use of tele-learning, rather than being diminished or threatened; not replacing what the University does well, but adding new dimensions to these old values. In the short time of this presentation, I will only be able to show a relatively few examples; in the WWW site I have prepared to support the demonstration, there will be links to other examples that those interested can study for as long as they wish. The address of this site is

http://www.to.utwente.nl/prj/diesrede/demo.htm

\section{ACADEMISCHE VORMING AND TELE-LEARNING}

The term "academische vorming" doesn't have an immediate parallel as a term in English ${ }^{3}$ although certainly the idea has. However it is an idea that is increasingly under strain as it comes in association with other ideas about the university experience, such as those related to making the university more and more open. However, I agree with our Rector that academische vorming is an important, old value, for our young students. Van Vught (1997) uses the phrase "intellectual expert", which I like as a goal of academische vorming. I will expand on his definition by noting the following characteristics of an "intellectual expert": someone who is trained in a discipline at a scientific level; has developed into an independent and critical thinker (including being able to be constructively critical of himself); is an individual who can take responsibility and leadership in a problem situation in practical situations where his discipline is relevant and participate in designing and testing a solution; an individual who can speak the language of his intellectual community, who knows its manners and style, who feels at home in its "branches" where ever they might be geographically.

How does a student mature into an intellectual expert? Certainly by studying, but also by undergoing an intellectual apprenticeship, with certain key components. The intellectual apprentice must know the tools of his trade, must be able to articulate his perceptions in the language of his profession, and must understand when this language is used well and when it is misused. This partially comes from reading books and listening to lectures, but just as a child learns the ways of his family, not only by observing and studying but by a continual process of trying the language out himself and receiving supportive re-enforcement and correction as he comes to define himself by the norms. This is similarly the case with academische vorming, or intellectual development. I believe this development requires the opportunity to practice finding one's voice in a professional community, to realise genuine success and failure in getting established in that community, and to have around one some persons who care enough to scaffold this process, giving

\footnotetext{
3 This is one of a number of terms that I find the Dutch language handles better than my native English; "vormgeving" is another.
} 
opportunities, encouragement and criticism. For the fortunate student at a good university, this initiation process, scaffolded by a wise mentor, gradually takes place.

How can tele-learning enhance this process? I can see many ways, of which the following are only some examples, taken from my own courses here at the University: 4

\begin{tabular}{|c|c|}
\hline $\begin{array}{l}\text { Aspect of Academische } \\
\text { Vorming }\end{array}$ & Example of Tele-Learning Enhancement \\
\hline $\begin{array}{l}\text { Guided collaboration with } \\
\text { external experts }\end{array}$ & $\begin{array}{l}\text { Writing chapters collaboratively, via e-mail and the WWW; } \\
\text { http://www.to.utwente.nl/ism/online/ }\end{array}$ \\
\hline $\begin{array}{l}\text { Guided communication with an } \\
\text { external expert }\end{array}$ & $\begin{array}{l}\text { Asking questions about the expert's work and getting a } \\
\text { response; http://www.to.utwente.nl/ism/isml- } \\
\text { 96/wwwproj/STUDYCTR/Week40/Fdbk40.htm }\end{array}$ \\
\hline $\begin{array}{l}\text { Learning to learn; practicing the } \\
\text { language }\end{array}$ & $\begin{array}{l}\text { Using "design guidelines" as vocabulary throughout a WWW- } \\
\text { based course; http://www.to.utwente.nl/ism/isml- } \\
\text { 97/wwwproj/studyctr/lin.htm and } \\
\text { http://www.to.utwente.nl/ism/ } \\
\text { ism l-97/wwwproj/prodctr/44eval.htm }\end{array}$ \\
\hline $\begin{array}{l}\text { Moving into a collegial } \\
\text { relationship with external experts }\end{array}$ & $\begin{array}{l}\text { Via the instructor's contacts, taking an active role in a } \\
\text { professional on-line discussion; } \\
\text { http://www.to.utwente.nl/prj/teled } 97 / \text { cwelcome.htm }\end{array}$ \\
\hline $\begin{array}{l}\text { Working with the instructor on } \\
\text { professional projects; mentoring } \\
\text { the student's initial public } \\
\text { presentations about his work }\end{array}$ & $\begin{array}{l}\text { Via cooperation with instructor on WWW-based projects and } \\
\text { scientific writing and presentations about the projects; } \\
\text { http://www.to.utwente.nl/ism/ism1-97/Edmedia/home.htmand } \\
\text { http://www.utwente.nl/prj/teled97/present/sld001.htm }\end{array}$ \\
\hline $\begin{array}{l}\text { Maintaining close communication } \\
\text { with the supervisor when on an } \\
\text { outside final (afstudeer) project }\end{array}$ & $\begin{array}{l}\text { Keeping in regular contact via the WWW; } \\
\text { http://www.dipoli.hut.fi/ hquirijn/weekrapport/pages/ }\end{array}$ \\
\hline
\end{tabular}

These are some of the types of professional experiences that differentiate academische vorming from taking a series of courses, in the way that the forest is more than the sum of the trees. Critical in these examples is the way that telematics can make it easier for a mentoring relationship between instructor and student to involve guided forays into real-world professional communities. Tele-learning techniques, used by the instructor interested in developing a mentor relationship with qualified students, can deepen and extend the opportunities for the student to find his voice and identity in a professional community. Thus it is not a matter of academische vorming OR tele-learning; it is a matter of both.

\footnotetext{
4 I am using examples from my own courses simply because I know them best and can conveniently offer them as examples. There are, of course, many other examples of tele-learning in the University besides my own courses. For courses making substantial use of WWW environments in the Faculty of Educational Science and Technology, see http://to-www.to.utwente.nl/TO/project/teletop/examples.html
} 


\section{BEING A GOOD TEACHER, AND TELE-LEARNING}

Here is perhaps where the greatest misconceptions appear about tele-learning. Many seem to assume that tele-learning means instructors no longer giving lectures, no longer being a "regular teacher", but moving to the background, even as in the Open University model, moving out of the picture entirely. I reject this. I feel the opposite. A good teacher who prepares good lectures and is effective in his class presentations should continue to exercise these skills, this craft, but can be even more effective with the addition of tele-learning techniques. To illustrate this, I will use the idea of the "Extended Lecture" that I use for all my lectures and also presentations.

An extended lecture is a lecture whose benefits begin before the lecture and last after the lecture, and where the actual lecture itself is improved, all through telelearning techniques. Here are examples:

\begin{tabular}{|c|c|}
\hline An Extended Lecture: & Examples: \\
\hline $\begin{array}{l}\text { Involves use of a WWW site to } \\
\text { present the lecture notes, as } \\
\text { interactive pages with links, before } \\
\text { the class }\end{array}$ & $\begin{array}{l}\text { Http://www.to.utwente.nl/ism/telearn/schedule/schedul.htm } \\
\text { and } \\
\text { http://www.to.utwente.nl/ism/telearn/schedule/Week18/virt- } \\
\text { uni//nter0.htm }\end{array}$ \\
\hline $\begin{array}{l}\text { During the lecture, invo'ves using this } \\
\text { same WWW site to illustrate points } \\
\text { with multimedia examples from other } \\
\text { sources. (And students who are not } \\
\text { physically present at the lecture can } \\
\text { interact with the same WWW site, } \\
\text { either while hearing the instructor in } \\
\text { real time, or via stored audio or video) }\end{array}$ & $\begin{array}{l}\text { Http://www.to.utwente.nl/user/ism/Collis/presents/Coimbra/in } \\
\text { dex.htm } \\
\text { Http://www.to.utwente.nl/topracl/telearn/www/group4/videos } \\
\text { um/video/htm/home.htm }\end{array}$ \\
\hline $\begin{array}{l}\text { After the lecture, students interact } \\
\text { individually with the links and } \\
\text { resources in the lecture notes, for } \\
\text { deeper study than possible in the } \\
\text { lecture and with reflective } \\
\text { communication added }\end{array}$ & $\begin{array}{l}\text { Http://www.to.utwente.nl/toprac 1/telearn/www/group4/videos } \\
\text { um/video/htm/opinion.htm }\end{array}$ \\
\hline $\begin{array}{l}\text { After the lecture, students can } \\
\text { supplement the lecture resources by } \\
\text { adding material to the WWW site }\end{array}$ & $\begin{array}{l}\text { Http://www.to.utwente.nl/ism/telearn/schedule/Week18/virt- } \\
\text { uni/inter6.htm }\end{array}$ \\
\hline
\end{tabular}

All of these examples show how a good teacher, who invests much care in his lectures, can extend those lectures, in depth, in time, and over distance, via telelearning.

There are many other aspects of being a good teacher, such as communicating personally with one's students, giving personal feedback, and keeping one's courses up to date and stimulating. For each of these points, I can show many examples of how tele-learning enhances good teaching, Here are just a few: 


\begin{tabular}{|l|l|}
\hline Aspects of being a good teacher: & Tele-learning support \\
\hline $\begin{array}{l}\text { Communicating personally with one's } \\
\text { students }\end{array}$ & $\begin{array}{l}\text { Via e-mail forms made handy within a course WWW site; } \\
\text { http://www.to.utwente.nl/ism/telearn/communic/communi } \\
\text { c.htm }\end{array}$ \\
\hline $\begin{array}{l}\text { Providing regular feedback and } \\
\text { models of good practice for } \\
\text { assignments }\end{array}$ & $\begin{array}{l}\text { Via model answers and links to examples of previous } \\
\text { work of students, http://www.to.utwente.nl/ism/ism1- } \\
97 / \text { wwwproj/studyctr/Week44/Int44.htm }\end{array}$ \\
\hline $\begin{array}{l}\text { Keeping one's course up-to-date and } \\
\text { stimulating }\end{array}$ & $\begin{array}{l}\text { Via external links and new sorts of activities such as } \\
\text { working collaboratively with students in another } \\
\text { university; } \\
\text { http://www.to.utwente.nl/ism/telearn/group/Grpp-wp.htm } \\
\text { and } \\
\text { http://www.to.utwente.nl/topracl/telearn/www/Group3/ho } \\
\text { me.htm }\end{array}$ \\
\hline
\end{tabular}

\section{LIVE LOCALLY, THINK GLOBALLY}

Another of the important old values of the university is to provide an environment in which participants not only benefit from proximity to each other, but also are aware of larger issues and patterns, beyond the local boundaries, and even backwards and forward in time. Academics have always been aware of larger boundaries for their ideas than only the local setting, and of course have long nourished their own work and that of their home universities by participating in international activities, such as going to a professional conference or working with colleagues from other institutions and countries on professional activities. Students also benefit from mobility during their study ${ }^{5}$. But until recently, much of this mobility was limited by the realities of costs--time and financial. Going away to an international conference is a special opportunity, perhaps once a year for an academic and never for a student, and often depends on finding adequate funding. Working on cross-border projects presents immediate and costly problems of getting everyone together and maintaining the momentum of work over time and distance. Studying abroad is valuable, but costs time and effort to organise, and sometimes becomes disruptive to the student's mainstream academic career.

Tele-learning is making all of these professional international experiences not only more accessible to staff and student alike, but also adds a new dimension to them. Here are just a few examples:

5 The conference, "Internationalisation and the University", co-sponsored by NUFFIC and the University of Twente in May 1997, provided an extended treatment of these points. 


\begin{tabular}{|l|l|}
\hline Internationalisation: & Tele-learning aspects: \\
\hline $\begin{array}{l}\text { Academics have new } \\
\text { opportunities for collaborative } \\
\text { projects with colleagues in } \\
\text { other locations }\end{array}$ & $\begin{array}{l}\text { Using a shared workspace via the WWW support collaborative } \\
\text { research sponsored by the EU; } \\
\text { http://bscw.dipoli.hut.fi/bscw/bscw.cgi(please note, this site } \\
\text { requires a password to enter, but I will demonstrate it during } \\
\text { the Rede) }\end{array}$ \\
\hline $\begin{array}{l}\text { Academics (and students) have } \\
\text { new opportunities to publish } \\
\text { and to extend the professional } \\
\text { conference experience }\end{array}$ & $\begin{array}{l}\text { WWW-extended conferences and video-conferencing at } \\
\text { conferences add to the quality and quantity of participation; } \\
\text { http://www.iste.org/conferences/teled97/webex/and } \\
\text { http://www.ieec.uned.es/ ifip97/ }\end{array}$ \\
\hline $\begin{array}{l}\text { Guest visitors can be integrated } \\
\text { into a lecture or a course or a } \\
\text { project, via telematics }\end{array}$ & $\begin{array}{l}\text { The external guest can lecture and interact in real time, and/or } \\
\text { can make his work available for further study after the lecture } \\
\text { or visit; http://itesm.cstudies.ubc.ca/(please note that this site } \\
\text { requires a password to enter, but I will demonstrate it during } \\
\text { the Rede) }\end{array}$ \\
\hline
\end{tabular}

The opportunities already available to University staff (and students) with respect to moving outside the local situation for stimulation or study or professional interaction are now on another dimension because of tele-learning. One's inner circle of professional colleagues can be scattered throughout the world, and it can be easier to communicate with this circle, using various telematics tools, than to communicate with those in one's own building. Important however, is not only the thinking globally, but the ability to translate the relevance of the global experience to one's local situation. This leads to another of the important old values of the University.

\section{AND ANOTHER OLD VALUE: THE UNIVERSITY AS EXPERTISE CENTRE}

Finally, the University values very much the service it can give to the community, the region, the country. By being acknowledged as a focal point of knowledge, as a centre of expertise, the University serves as a valuable partner in many different projects. Telematics makes these partnerships, at the very least, more efficient, as partners do not need to always travel to meetings and potential partners can find what the University offers and who to contact with support of different information channels, including those involving telematics and in particular WWW sites. Telematics is not only a channel but also a focal point for the University of Twente in many of its partnership activities. Increasingly, the local, regional, national, and international community look to us as a centre of excellence with respect to telematics and telematics applications (including tele-learning). Some of the many examples are shown below: 


\begin{tabular}{|l|l|}
\hline Focal Point: & Partnership \\
\hline Telematics expertise nationally & $\begin{array}{l}\text { The Telematics Institute; } \text { http://www.trc.nl/ttti/indextti.htm; } \\
\text { the MESH Project, http://www.mesh.nl/extern/english.html }\end{array}$ \\
\hline $\begin{array}{l}\text { Tele-learning expertise within } \\
\text { the University }\end{array}$ & $\begin{array}{l}\text { The PTIT-IDYLLE } \\
\text { http://wwwctit.cs.utwente.nl/Docs/research/project/idylle/IDYL } \\
\text { LE.htm }\end{array}$ \\
\hline $\begin{array}{l}\text { Tele-learning expertise } \\
\text { internationally }\end{array}$ & The European School Network(EUN), http://www.eun.org/ \\
\hline
\end{tabular}

In all of these, telematics is being used in a learning-related context for responsive service and partnership with many different communities. The University of Twente continues to strengthen its international profile in this area; it has already become a focal point for knowledge and expertise with respect to telematics applications.

\section{BUT, THERE IS A SECOND SIDE TO THE METAPHOR}

The last examples have focused on a positive message associated with the metaphor "New wine and old bottles". Tele-learning is the new wine, our old values are the old bottles, and the fermenting of the new wine in these old bottles brings a valuable result: the old values are strengthened.

But there is, unfortunately, another way to interpret the metaphor. This way comes as a warning. "New wine in old bottles" can lead to a sorry result. Many years ago a truly great teacher made the following observation:

"..no one pours new wine into old wineskins; else the new wine will burst the skins and will be split itself, and the skins ruined. New wine must be put into new wineskins, and then both will be saved" (Luke 5:37, Chalmers-Rheims Version, translation 1954)

The metaphor here is striking: old wineskins in the Biblical time were brittle; new wine ferments, at a certain point the fermentation causes the old wineskins to burst. Both new and old are lost. There is also a message for us in this side of the metaphor. When the "old bottles" represent old procedures, old ways of doing things, that no longer are a good reflection of our old values, it is those old ways that must be replaced before, or after, the fermentation of the new wine of telematics applications bursts their seams.

\section{SOME OLD WINESKINS...}

Two "old wineskins" are in particular danger from the fermentation of tele-learning in the university, not only our own university but worldwide ${ }^{6}$. The first of these is

${ }^{6}$ For an on-going debate about the impact of telematics on the future university, the Vision 2010 University site maintained at the University of Michigan is a good source (http://www.si.umich.edu/V2010/). Also, the work of Tiffin and 
our "assembly line" approach to higher education ("Fordism") 7 and the second is intellectual parochialism.

In gradual response to the very positive motivation of providing qualitycontrolled and affordable university education to a maximal number of students, we have seen the development of a so-called "Fordism" or assembly line approach $^{8}$. It is now assumed that a quality product will come off the assembly line after a set amount of courses, in a set amount of time, starting directly after secondary school, and this product will be road-ready, presumably forever, after this processing. Presumably forever, in terms of government funding policies, because there is no systematic provision for funding for study at the university after the end of this assembly-line period. Already many universities in other countries, particularly Canada and Australia, are breaking away from this Fordism approach, and investing as much systematic attention to what is often called "Continuing Education", or provision for life-long learning as they do to the firstphase learning9. Offering courses and programmes to professionals is not only motivated by a post-Fordist philosophy, but also by strong economic factors: the life-long learning market presents an important new client base for the University.

But re-tooling one's assembly line, to continue this metaphor, needs to be done at many different levels before the University of Twente can say it is truly responding to life-long learning. This will require not only the new wine of tele-learning, but will also inevitably result in the need for new ways, new procedures, new approaches to curriculum and academic programmes and funding and to staff time allocation and facility allocation throughout the University. The old ways will simply split at the seams as this fermentation continues.

And another old way that will split with change is what I call "intellectual parochialism". Self-enclosed thinking and teaching, self-feeding on its own work and ideas, will no longer be acceptable in the future university. The synergy between local and global will become so powerful in society as a whole, and the impact of telematics so pervasive and ubiquitous in all aspects of our commerce

Rajasingham in New Zealand (via their 1995 book In search of the virtual class and the evolving Global Virtual University (http://206.154.197.130:80/VU/) which Tiffin is involved in founding) are useful to study.

7 Volume 17(2), 1996, of the Austrialasian journal Distance Education (http://www.usq.edu.au/dec/decjourn/v17n296/issue.htm) discusses the evolution of Fordism in higher education at a particularly thoughtful level.

8 I discuss this at some length in the final chapter of my Tele-learning in a Digital World book.

9 See for example, the Life-Long Learning Institute at the Helsinki University of Technology, in Finland (http://www.dipoli.fi/eng/index.htm) 
and culture, that the instructor who figuratively and literally lectures from old notes, who sees the world through his own research, who is bound within his own walls, will be as much of an anachronism as the candle, the horse-drawn carriage, the butter churn; nice for romantic occasions or for a sense of history but not tools to be funded by society.

Thus my use of the metaphor of "New Wine and Old Bottles" is deliberate for this rede, because it is a metaphor that captures both sides of tele-learning: When the old bottles are the old values of the University, these old values are not brittle wineskins vulnerable to bursting with the fermentation of the new wine, but elastic and flexible. Extending the University experience beyond the confines of time, place, and person allows us--staff and students--to live locally and globally simultaneously, to magnify the opportunities we can scaffold for the professional initiation and the intellectual development of our students, and to strengthen our profile as a leader with respect to applications of telematics. But when the old bottles are old ways of doing things that no longer parallel the old values, then these are old wineskins such as the Bible warns about.

\section{SOME REFLECTIONS ON THE NEW WINE...}

In all these comments, I have been talking about tele-learning as a New Wine in a way that has not been very differentiating. It is important to note that jus as "old bottles" can be seen in different ways, so can the "new wine" of tele-learning. To extend the wine metaphor even more:

Not every batch of new wine will mature into a great vintage

Not all forms of new wine will be valued over time

Some variants of new wine will achieve no more than local consumption

Some variants of new wine will not last long enough to even ferment

And, not everyone wants to drink wine...

I see much of my own work focused on these points (relating to learning, not wine, of course!). Which tele-learning applications will emerge as those gaining a critical mass of acceptance and impact in practice? Can we predict these now? I think so, but that is a story for another speech...

\section{OUR TASK AT THE UNIVERSITY OF TWENTE?}

I see it as our job at the University of Twente to lead the way in "spotting the great vintages" in terms of telematics applications in society, and thus with respect to tele-learning. Once we spot these great vintages, we need to identify the ways their fermentation can be used to enhance our old values. But we also need to anticipate and reduce the painful impact of this fermentation on many of our old procedures, our old ways of doing things, even our old securities.

At the University of Twente, we have had a head start in pioneer work with applications of telematics in many different fields, including in education, and to 
this we owe much to the vision and strategy of our Board. The start of the Centre for Telematics and Information Technology, (http://wwwctit.cs.utwente.nl) for example, was an important strategic move for the telematics profile of the University. The decisions taken to supply all our students with good connections to the University network and the Internet was also bold and important to all of our subsequent tele-learning initiatives. The climate of encouragement as well as the real support provided by the Board for telematics initiatives is a critical factor in our success as pioneers in many different telematics-related areas.

But, the rest of the academic world is catching up on many of our pioneering ideas. The course "On-Line Learning" (see http://www.to.utwente.nl/ism/online/) was a pioneer in the use of the WWW as a course environment in early 1994; now every university in the Western world uses the WWW in some way in relation to its courses (even if only for the conceptually simplest form of information dissemination). Our involvement, through CTIT, in multi-partner projects involving high-speed networking and its applications to different areas including education was more unique in 1995 when we began participation in the PLATINUM Project than it is now when many such collaborative explorations of ATM and other forms of high-speed, high bandwidth networking are occurring in countries throughout the world.

I believe we have reached a critical point: Even as we continue to strive for pioneering insights in our research and practice with respect to tele-learning, we need to turn our energy and expertise to a new challenge: impiomentation, or sustainable use throughout the institution.

There is a critical gap between the vision and energy of pioneers and the institutionalisation of this vision and energy into sustainable practice ${ }^{10}$. Sustainable practice is what I mean by implementation: Once we identify what aspects of tele-learning are potential "great vintages", how do we move to support their growth in as systematic and professional way as possible? There are many, many problems when change occurs in an educational institution; this is well known in the literature and in practice. Here is where I see our real potential for leadership in tele-learning now lies: How can we manage its acceptance into educational practice enough so that the fermentation reaches a critical mass of impact?

\footnotetext{
${ }^{10} \mathrm{I}$ have made an analysis of this in a speech to be presented to representatives of all Dutch universities and hogeschools in December (see http://www.to.utwente.nl/user/ism/Collis/papers/suncoo.doc). In this speech, I identify three phases: pioneer, " 1.000 flowers blooming", and managed change.
} 


\section{THE NEW CHALLENGE: TELETOP AT THE FACULTY OF EDUCATIONAL SCIENCE AND TECHNOLOGY}

I believe that my faculty, Toegepaste Onderwijskunde (T.O.), is again embarking on pioneer work with respect to tele-learning, but this time in the implementation aspect. Because of the range and depth of experience with tele-learning in our faculty, our own faculty Board has taken a visionary and strategic step. A major project has begun, called TeleTOP (the Tele-Learning at TO Project), which has as a concrete goal the systematic adaptation of approximately 15 of our courses, this year, to a more flexible form through the combination of new didactics and WWW-based environments. This more flexible form will be immediately put to test through its application with the many students who now participate in our Master of Science Programme in Educational and Training Systems Design (http://www.to.utwente.nl/masters/mscgen.htm) as well as new cohorts of part-time students for whom WWW-based course support can allow full participation in our education while continuing with their work. TeleTOP is both a top-down and bottom-up initiative: from top-down, we offer strong professional and technical support, guidance, and strategy, while from bottom-up we recognise the critical importance of faculty acceptance and buy-in and are seeking for each instructor the particular form and mix of tele-learning techniques with other aspects of instruction that will best fit his or her vision of good teaching. We invite everyone to visit the homesite of TeleTOP to follow our progress:

http://to-www.to.utwente.nVTO/project/teletop/

Through TeleTOP, as well as other initiatives such as those in other faculties, those being supported by the $O C$ (Onderwijskundig Centrum), and those within the framework of the CTIT (such as the IDYLLE Project) we will, again, move forward at the University of Twente as a leader in tele-learning, in the combination of new wine, old values and new methods that we celebrate today at this anniversary.

So, as we say in English at a birthday or anniversary celebration, "Many Happy Returns!" I suggest we use today as a benchmark, and look together again, in five years' time, to see what those returns, related to tele-learning, have been.

\section{REFERENCES}

Collis, B. (1996a). Tele-learning in a digital world: The future of distance learning. London: International Thomson Publications.

Collis, B. (1996b). The Internet as an educational innovation: Lessons from experience with computer implementation. Educational Technology, 36(7), 2130.

Tiffin, J., \& Rajasingham, L. (1995). In search of the virtual class: Education in an information age. London: Routledge.

Van Vught, F. (1997). Academische vorming: over experts en intellectuelen. Rede, opening academsich jaar 1997/1998, Universiteit Twente, Enschede, NL. 


\section{BIOGRAPHY}

Betty Collis is an Associate Professor in Educational Instrumentation at the University of Twente. Since 1980, she has been acknowledged internationally as a specialist in computers in education, and since the mid 1980s, in telecommunications in education. Her major activity at the moment is being Chair of the TeleTOP Project, in which the faculty is re-designing its courses through the use of a combination of telematics applications, not only to make the courses themselves more flexible but more than this, to move toward a new model of teaching and learning in higher education. 